University of Nebraska - Lincoln

DigitalCommons@University of Nebraska - Lincoln

\title{
Comparison of Laboratory Methods and an In Situ Method for Estimating Nitrogen Mineralization in an Irrigated Silt-Loam Soil
}

\author{
Brian J. Wienhold \\ Soil and Water Conservation Research Unit, USDA-ARS, Brian.Wienhold@ars.usda.gov
}

Follow this and additional works at: https://digitalcommons.unl.edu/usdaarsfacpub

Part of the Agricultural Science Commons

\footnotetext{
Wienhold, Brian J., "Comparison of Laboratory Methods and an In Situ Method for Estimating Nitrogen Mineralization in an Irrigated Silt-Loam Soil" (2007). Publications from USDA-ARS / UNL Faculty. 174. https://digitalcommons.unl.edu/usdaarsfacpub/174
}

This Article is brought to you for free and open access by the U.S. Department of Agriculture: Agricultural Research Service, Lincoln, Nebraska at DigitalCommons@University of Nebraska - Lincoln. It has been accepted for inclusion in Publications from USDA-ARS / UNL Faculty by an authorized administrator of DigitalCommons@University of Nebraska - Lincoln. 


\title{
Comparison of Laboratory Methods and an In Situ Method for Estimating Nitrogen Mineralization in an Irrigated Silt-Loam Soil
}

\author{
Brian J. Wienhold \\ Soil and Water Conservation Research Unit, USDA-ARS, University of \\ Nebraska, Lincoln, Nebraska, USA
}

\begin{abstract}
Nitrogen $(\mathrm{N})$ mineralization makes a considerable contribution to cropavailable $\mathrm{N}$ and is difficult to estimate. Reliable methods for measuring $\mathrm{N}$ mineralization are needed to produce data sets for developing $\mathrm{N}$-mineralization models, as a component in fertilizer recommendation algorithms, and to assess the effect of management practices on $\mathrm{N}$ mineralization. Numerous methods are available for estimating $\mathrm{N}$ mineralization. Laboratory methods are relatively easy but may not reflect conditions in the field, and field methods are usually labor-intensive. A study was conducted to compare N-mineralization estimates using anaerobic and aerobic laboratory methods and an in situ field method for the 0 - to $15-\mathrm{cm}$ depth of a silt loam soil under irrigated corn (Zea mays L.). Mineralization estimates were also compared to $\mathrm{N}$ mineralization based on crop $\mathrm{N}$ content. Estimates of $\mathrm{N}$ mineralization were $101 \mathrm{~kg} \mathrm{ha}^{-1}$ for the anaerobic laboratory method, $284 \mathrm{~kg} \mathrm{ha}^{-1}$ for the aerobic laboratory method, and $134 \mathrm{~kg} \mathrm{ha}^{-1}$ for the in situ field method. The in situ field method provided a reasonable estimate of $\mathrm{N}$ mineralization ( 0 to $15 \mathrm{~cm}$ ) when compared to the estimate of mineralized $\mathrm{N}$ (root zone) based on crop $\mathrm{N}$ content $\left(215 \mathrm{~kg} \mathrm{ha}^{-1}\right)$. The in situ field method can be used to measure $\mathrm{N}$ mineralization during the growing season and for comparing $\mathrm{N}$ mineralization among management practices.
\end{abstract}

Keywords: Corn, nitrogen, Zea mays $\mathrm{L}$

Received 17 July 2006, Accepted 15 August 2006

Address correspondence to Brian J. Wienhold, SWCRU, USDA-ARS, 122 Keim Hall, East Campus, University of Nebraska, Lincoln, NE 68583, USA. E-mail: bwienhold1@unl.edu 


\section{INTRODUCTION}

Nitrogen $(\mathrm{N})$ is the nutrient most often limiting crop production and is the most commonly applied fertilizer element. In addition to fertilizer inputs, other possible sources of $\mathrm{N}$ to a crop include residual soil inorganic $\mathrm{N}$; $\mathrm{N}$ fixed by legumes; atmospheric deposition; $\mathrm{N}$ in irrigation water; mineralization of crop residue, manure, or compost; and soil organic matter. Underestimation of $\mathrm{N}$ from other sources results in application of excess fertilizer $\mathrm{N}$, leading to the potential for environmental contamination due to leaching and runoff losses.

Mineralization contributions to plant-available $\mathrm{N}$ can be substantial and are difficult to estimate. Laboratory incubations are the most common approach for estimating mineralization rates. Laboratory incubation methods are conducted under temperature and moisture conditions different than those in the field, and therefore laboratory results may not accurately depict mineralization in the field. In situ mineralization methods are timeconsuming but are conducted under more realistic temperature and moisture conditions. One method that has potential for measuring mineralization under field conditions involves in situ incubation of intact soil cores with resin traps below the soil core for adsorbing inorganic $\mathrm{N}$ leached from the core (Distefano and Gholz 1986).

In agricultural systems, the in situ method utilizing ion exchange resins has been used to measure $\mathrm{N}$ mineralization in soils amended with beef feedlot manure and compost (Eghball 2000) and among cropping systems in a dryland setting (Kolberg et al. 1997). Hanselman, Graetz, and Obreza (2004) compared several in situ methods and concluded that the intact soil core with resin traps provided more reasonable estimates of mineralization than the other methods tested. However, they identified potential problems for the intact soil core in situ method, including the potential for resin saturation and bypass flow when soil cores were left in the field for extended periods (180 days). Hanselman, Graetz, and Obreza (2004) conducted their study on a coarse-textured soil receiving large amounts of precipitation $(780 \mathrm{~mm})$ and applied high amounts of $\mathrm{N}(225$ to $\left.1425 \mathrm{~kg} \mathrm{ha}^{-1}\right)$. In contrast, Eghball (2000) reported that $35 \mathrm{~cm}^{3}$ of combined anion and cation resin retained inorganic $\mathrm{N}$ equivalent to $275 \mathrm{~kg} \mathrm{ha}^{-1}$ in a study conducted on a silty clay loam receiving an average of $350 \mathrm{~mm}$ of precipitation. Given the potential problems and time required for in situ determination of $\mathrm{N}$ mineralization and uncertainty about the accuracy of laboratory estimates of $\mathrm{N}$ mineralization information regarding comparisons among methods is needed.

There have been few studies comparing laboratory and in situ mineralization methods. The objective of this study was to compare $\mathrm{N}$ mineralization estimates determined using an in situ method and two laboratory methods. These $\mathrm{N}$ mineralization estimates were also compared to estimates of the contribution mineralized $\mathrm{N}$ made to crop $\mathrm{N}$ content. 


\section{MATERIALS AND METHODS}

\section{Study Site}

The study site was located in central Nebraska in Buffalo County near the town of Shelton $\left(40^{\circ} 45^{\prime} 01^{\prime \prime} \mathrm{N}, 98^{\circ} 46^{\prime} 01^{\prime \prime} \mathrm{W}\right)$. The soil at the site was a Hord silt loam (fine-silty, mixed mesic pachic Argiustoll, 0-1\% slope). The field has been cropped to irrigated continuous corn (Zea mays L.) for at least 10 years. Typical field operations include tillage with a tandem disk to incorporate crop residue following combine harvest, preplant application of $170 \mathrm{~kg} \mathrm{ha}^{-1} \mathrm{~N}$ as a $32 \% \mathrm{~N}$ urea ammonium nitrate solution incorporated with a field cultivator, application of $90 \mathrm{~L} \mathrm{ha}^{-1}$ of $10-34-0+\mathrm{Zn}$ at planting, planting at a density of 70,000 seeds $\mathrm{ha}^{-1}$, and pesticide applications at recommended rates for insect and weed control. The field is cultivated at the V6 growth stage (Ritchie, Hanway, and Benson 1993) and, depending on growing season precipitation, 20 to $30 \mathrm{~cm}$ of irrigation water is usually applied. In 2004, the field average grain yield at $155 \mathrm{~g} \mathrm{~kg}^{-1}$ moisture was $14.1 \mathrm{Mg} \mathrm{ha}^{-1}$.

To reduce variability among sample sites, apparent electrical conductivity (ECa) was used to delineate classes within the field that have soils with similar inherent properties. The approach used was similar to that of Johnson et al. (2001) where ECa measured with an EM-38 (Geonics Inc., Mississauga, ON, Canada), georeferenced using a Trimble TDC 1 global positioning system (Trimble Navigation Ltd., Sunnyvale, CA), was coded into four classes using an unsupervised classification procedure in ERDAS Imagine (ERDAS Inc., Atlanta, Ga.). The classes having the lowest and highest average ECa were selected for use in this study. Within each of those two classes, six random sites were selected for soil sampling, in situ determination of $\mathrm{N}$ mineralization, and plant harvest for determination of biomass and $\mathrm{N}$ concentration.

\section{N-Mineralization Methods}

Two laboratory methods and an in situ field method were compared. Soil for the laboratory methods was collected from the $0-$ to $15-\mathrm{cm}$ depth at six sites within each of the two selected ECa classes within the field. Soil was maintained at field moisture content, passed through a 4-mm sieve to remove large pieces of crop residue, and stored at $4{ }^{\circ} \mathrm{C}$ until used to estimate $\mathrm{N}$ mineralization. Soils were analyzed for bulk density (Blake and Hartge 1986), texture (Kettler, Doran, and Gilbert 2001), pH and electrical conductivity (EC) (Smith and Doran 1996), total carbon (C) and N (Schepers, Francis, and Thompson 1989), extractable phosphorus (P) (Bray and Kurtz 1945), and inorganic $\mathrm{N}$ (Keeney 1982). Based on $\mathrm{pH}$ and lack of reactivity to acid, all soil $\mathrm{C}$ was assumed to be in the organic form. 
The first laboratory method for estimating $\mathrm{N}$ mineralization was the anaerobic incubation method of Waring and Bremner (1964). Briefly, $5 \mathrm{~g}$ of soil and $10 \mathrm{~mL}$ of water are placed in a tube, sealed with a stopper, and incubated at $40^{\circ} \mathrm{C}$ for 7 days. Ammonium $\left(\mathrm{NH}_{4}\right)-\mathrm{N}$ concentration is then determined. The second laboratory method for estimating $\mathrm{N}$ mineralization was the aerobic incubation method of Stanford and Smith (1972). Briefly, $15 \mathrm{~g}$ of soil and $15 \mathrm{~g}$ of silica sand were mixed and transferred to a polystyrene filtration unit fitted with a $22-\mu \mathrm{m}$ cellulose acetate membrane (Corning, Inc., Corning, N.Y.). The soil mixture was leached with $100 \mathrm{~mL}$ of $0.01 \mathrm{M}$ calcium chloride $\left(\mathrm{CaCl}_{2}\right)$, followed by application of a slight vacuum to bring the soil mixture to a standard water content. Soils were incubated at $25^{\circ} \mathrm{C}$, weighed periodically, and had water added to maintain a constant moisture content. Soils were leached with $0.01 \mathrm{M}$ $\mathrm{CaCl}_{2}$ every 14 days over the 84-day incubation. Inorganic $\mathrm{N}$ was determined in both laboratory methods colorimetrically using a Lachat flow injection ion analyzer (Zellweger Analytics, Lachat Instruments Div., Milwaukee, Wisc.).

The in situ $\mathrm{N}$ mineralization method used was similar to that described by Kolberg et al. (1997). Briefly, a 4.75-cm diameter metal cylinder was inserted $17 \mathrm{~cm}$ into the soil, and the cylinder containing an intact soil core was removed from the soil. Two $\mathrm{cm}$ of soil was removed from the bottom of the cylinder, and a nylon bag containing $35 \mathrm{~cm}^{3}$ of a $1: 2$ mixture of sodium (Na)-saturated cation (C-249) and chloride $(\mathrm{Cl})$-saturated anion (ASB-1P) resin (Sybron Chemical Inc., Birmingham, N.J.) was inserted into the bottom of the cylinder. The bottom of the core was then covered with heavy nylon cloth to prevent root entry, and the cylinder was reinserted into the original hole. Cylinders were inserted between corn plants in the row. Twenty cylinders were inserted at six sites within each of the two ECa classes on June 6, 2004. Initial inorganic $\mathrm{N}$ content was determined in soil samples collected from the 0 - to $15-\mathrm{cm}$ depth when the cylinders were installed. Soil temperature was recorded four times daily using a temperature recorder (Onset computer Corp., Bourne, Mass.) buried at a depth of $10 \mathrm{~cm}$. Four cylinders at each site were randomly selected for removal 28, 48, 67, 88, and 118 days after installation. A soil sample from the $0-$ to $15-\mathrm{cm}$ depth was collected for determination of gravimetric soil water content each date that cylinders were collected. Resin from the four cylinders was combined and stored at $4{ }^{\circ} \mathrm{C}$ until analyzed for inorganic N. Soil was removed from the four cylinders, composited, air dried, and ground to pass a 2-mm sieve. Inorganic $\mathrm{N}$ in soil was determined by $2 \mathrm{M}$ potassium chloride $(\mathrm{KCl})$ extraction (Keeney 1982). Inorganic $\mathrm{N}$ in resin was extracted by five 15min serial extractions with $2 \mathrm{M} \mathrm{KCl}$ (Kolberg et al. 1997). Inorganic N was determined in all extracts colorimetrically using a Lachat flow injection ion analyzer (Zellweger Analytics, Lachat Instruments Div., Milwaukee, Wisc.). 


\section{Biomass Harvest}

At maturity, plants from $2 \mathrm{~m}$ of the row were collected at the six sites in both ECa classes. Grain and stover were separated, dried, weighed, ground, and analyzed for total $\mathrm{N}$ by dry combustion (Schepers, Francis, and Thompson 1989). Dry weight and N concentration were used to calculate $\mathrm{N}$ content of aboveground crop biomass.

\section{Data Analysis}

Net $\mathrm{N}$ mineralization based on anaerobic incubation was calculated by subtracting the initial $\mathrm{NH}_{4}-\mathrm{N}$ concentration from the final $\mathrm{NH}_{4}-\mathrm{N}$ concentration and converted to a volumetric basis using measured bulk densities for the 0 - to $15-\mathrm{cm}$ depth at each site. Net $\mathrm{N}$ mineralization based on the aerobic incubation was calculated by subtracting initial inorganic $\mathrm{N}$ concentration from inorganic $\mathrm{N}$ concentration in the leachate after 14 days of incubation and summing inorganic $\mathrm{N}$ contained in the five subsequent leachates. Cumulative inorganic $\mathrm{N}$ was converted to a volumetric basis using measured bulk densities for the 0 - to $15-\mathrm{cm}$ depth at each site. Net $\mathrm{N}$ mineralization based on the in situ method was calculated by summing inorganic $\mathrm{N}$ from soil and resin, subtracting inorganic $\mathrm{N}$ additions from the irrigation water, and subtracting inorganic $\mathrm{N}$ present in the soil when the cylinders were installed. Net $\mathrm{N}$ mineralization was converted to a volumetric basis for the 0 - to 15-cm depth based on the cross-sectional area of the cylinder.

Potential $\mathrm{N}$ mineralization was also calculated using results from the aerobic laboratory incubation and the in situ field method. Cumulative $\mathrm{N}$ mineralized as a function of time for each of these methods was fit to the following equation (Griffin and Honeycutt 2000):

$$
\mathrm{N}_{\mathrm{t}}=\mathrm{N}_{\mathrm{o}}(1-\exp [-\mathrm{k} \text { GDD }])
$$

where $\mathrm{N}_{\mathrm{t}}$ is the amount of $\mathrm{N}$ mineralized, GDD is accumulated degree days (summation of average daily temperature from cylinder installation or initiation of incubation), $\mathrm{N}_{\mathrm{o}}$ is the potentially mineralizable $\mathrm{N}$, and $\mathrm{k}$ is the apparent mineralization rate constant. Nonlinear regression (SAS Institute 1985) was used to estimate $\mathrm{N}_{\mathrm{o}}$ and $\mathrm{k}$.

Analysis of variance was used to determine differences in net or $\mathrm{N}_{\mathrm{O}}$ among the methods (SAS Institute 1985). The experimental design was completely random with two field classes (ECa 1 vs. ECa 2) and five $\mathrm{N}$-mineralization estimates [in situ fitted to Eq. (1), in situ summed, aerobic laboratory incubation fitted to Eq. (1), aerobic laboratory incubation summed, and anaerobic laboratory incubation] with six replications. Differences were declared significant at the 0.05 probability level. Differences among means were determined by pairwise comparisons made with the 
DIFF option of the LSMEANS statement. The Tukey adjustment option of the LSMEANS statement was used to protect the experiment error rate.

\section{RESULTS AND DISCUSSION}

Soil within the two ECa classes selected for use in this study differed in texture, organic $\mathrm{C}$, Bray $\mathrm{P}$, and $\mathrm{NO}_{3}-\mathrm{N}$ (Table 1). Hence, ECa was effective in delineating soil into classes that differed in physical and chemical properties that potentially have agronomic significance. These results are consistent with those of Johnson et al. (2001), who reported that ECa was an effective tool for delineating field-scale soil spatial variability. Inherent soil properties such as clay content and organic matter content have been shown to influence ECa measurements in nonsaline soils (Sudduth et al. 2003), and dynamic soil properties such as $\mathrm{NO}_{3}-\mathrm{N}$ concentration have been monitored during the growing season using ECa (Eigenberg et al. 2002).

Estimates of $\mathrm{N}$ mineralization did not differ between the two $\mathrm{ECa}$ classes $(\mathrm{P}=0.38)$, and there was no interaction between ECa class and method $(\mathrm{P}=0.73)$. Similarly, estimates of $\mathrm{k}$ did not differ between the ECa classes $(\mathrm{P}=0.51)$, and there was no interaction between ECa classes and methods $(\mathrm{P}=0.84)$. Therefore, only differences in estimated $\mathrm{N}$ mineralization and $\mathrm{k}$ among the methods will be presented. Lack of differences between the two ECa classes for any of the methods suggests that the differences in physical and chemical properties between the two sites are not great enough to affect biological processes related to mineralization. Grain and drymatter yields were also similar between the two ECa classes. Dry matter returned to the soil is the main substrate for decomposition and mineralization. Because similar amounts of dry matter were returned to the soil, it is

Table 1. Physical and chemical properties for the Hord silt loam soil

\begin{tabular}{|c|c|c|}
\hline Soil property & ECa class 1 & ECa class 2 \\
\hline Bulk density $\left(\mathrm{g} \mathrm{cm}^{-3}\right)$ & $1.52 \pm 0.04^{a}$ & $1.53 \pm 0.02$ \\
\hline Sand $\left(\mathrm{g} \mathrm{kg}^{-1}\right)$ & $372 \pm 28$ & $362 \pm 9$ \\
\hline Silt $\left(\mathrm{g} \mathrm{kg}^{-1}\right)$ & $432 \pm 22$ & $320 \pm 4$ \\
\hline Clay $\left(\mathrm{g} \mathrm{kg}^{-1}\right)$ & $196 \pm 10$ & $318 \pm 4$ \\
\hline $\mathrm{pH}$ & $6.6 \pm 0.1$ & $6.3 \pm 0.1$ \\
\hline Electrical conductivity $\left(\mathrm{dS} \mathrm{m}^{-1}\right)$ & $0.46 \pm 0.05$ & $0.52 \pm 0.04$ \\
\hline Organic carbon $\left(\mathrm{g} \mathrm{kg}^{-1}\right)$ & $12.5 \pm 0.8$ & $13.3 \pm 0.1$ \\
\hline Total nitrogen $\left(\mathrm{g} \mathrm{kg}^{-1}\right)$ & $1.2 \pm 0.1$ & $1.2 \pm 0.1$ \\
\hline Bray phosphorus $\left(\mathrm{mg} \mathrm{kg}^{-1}\right)$ & $13.6 \pm 2.3$ & $29.1 \pm 8.8$ \\
\hline $\mathrm{NO}_{3}-\mathrm{N}\left(\mathrm{mg} \mathrm{kg}^{-1}\right)$ & $21.3 \pm 4.8$ & $30.7 \pm 3.8$ \\
\hline $\mathrm{NH}_{4}-\mathrm{N}\left(\mathrm{mg} \mathrm{kg}^{-1}\right)$ & $1.1 \pm 0.1$ & $1.3 \pm 0.1$ \\
\hline
\end{tabular}

${ }^{a}$ Mean \pm standard error. 
reasonable that similar amounts of $\mathrm{N}$ were mineralized at sites within the two ECa classes.

Estimates of $\mathrm{N}$ mineralization differed nearly fivefold among the methods used in this study. The aerobic laboratory method gave the highest estimates, while the anaerobic laboratory method gave the lowest estimates of $\mathrm{N}$ mineralization (Table 2). When the results from the aerobic laboratory incubation were fit to Eq. (1), the estimate for $\mathrm{N}_{\mathrm{o}}$ was $65 \%$ greater than the summed estimate for aerobic incubation $\mathrm{N}$ mineralized. Values for $\mathrm{N}_{\mathrm{o}}$ represent potentially mineralizable $\mathrm{N}$, whereas summed results represent the amount of $\mathrm{N}$ actually mineralized under temperature and moisture conditions used in this study. The higher estimates for $\mathrm{N}$ mineralization for the aerobic laboratory method, for summed or fitted results, are likely due to the fact that estimates determined using this method are obtained for soils incubated under ideal temperature and moisture conditions. When compared to the other methods, the low estimates for $\mathrm{N}$ mineralization obtained using the anaerobic laboratory method may be due to the short incubation period ( 7 days) and because different substrates within the soil are utilized under anaerobic conditions than under aerobic conditions in the other methods. Gianello and Bremner (1986) also found that the anaerobic incubation method provided lower estimates of $\mathrm{N}$ mineralization than provided by the aerobic laboratory incubation for a range of soils in Iowa.

Estimates of $\mathrm{N}$ mineralization for the in situ method were calculated two ways, summed over the five sampling dates or fitted to Eq. (1). Summing the values provides an estimate of the amount of $\mathrm{N}$ mineralized over the time period the corn crop was actively taking up N, and fitting the data to Eq. (1) provides an estimate of $\mathrm{N}_{\mathrm{o}}$ under field conditions for the 2004 growing season. Estimates for the in situ method calculated in these two ways were statistically similar (Table 2). Estimates for $\mathrm{N}_{\mathrm{o}}$ in this study are nearly two fold greater than those reported by Eghball (2000), who used a similar in situ method to estimate $\mathrm{N}$ mineralization in a silty clay soil under rainfed conditions. The lower estimates reported by Eghball (2000) are likely due to much drier soil conditions during the growing season.

Table 2. Mineralizable $\mathrm{N}$ and rate constants

\begin{tabular}{lll}
\hline Method & $\begin{array}{c}\text { Mineralizable N } \\
\left(\mathrm{kg} \mathrm{ha}^{-1}\right)\end{array}$ & $\begin{array}{c}\text { Rate constant (growing } \\
\text { degree days }\end{array}$ \\
\hline In situ fitted & $139.2 \pm 20.2 \mathrm{C}^{a}$ & $0.0026 \pm 0.0005$ \\
In situ summed & $134.2 \pm 15.6 \mathrm{CD}$ & n.a. \\
Aerobic incubation fitted & $466.0 \pm 48.4 \mathrm{~A}$ & $0.0006 \pm 0.00008$ \\
Aerobic incubation summed & $284.0 \pm 15.2 \mathrm{~B}$ & n.a. \\
Anaerobic incubation & $101.4 \pm 7.4 \mathrm{D}$ & n.a. \\
\hline
\end{tabular}

\footnotetext{
${ }^{a}$ Mean \pm standard error; means followed by different letters are different at $\mathrm{p}<0.05$.
} 
Estimates of $\mathrm{N}$ mineralization for the in situ method were lower than those for the aerobic laboratory incubation. The aerobic laboratory incubation was conducted using well-mixed soil under optimal soil temperature and water conditions, whereas the in situ method was conducted using an intact soil core under variable soil temperature and water conditions. Average daily soil temperatures for the in situ method were cooler than those in the aerobic laboratory incubation (Figure 1). There were only three short time periods where average daily soil temperatures in the field approached the $25^{\circ} \mathrm{C}$ temperature used in the aerobic laboratory incubation. Soil temperatures in the laboratory incubation were constant, whereas those in the field fluctuated between 12 and $26^{\circ} \mathrm{C}$ over the study period. Similarly, soil moisture content fluctuated during the growing season; soil in the cylinders was from 50 to $75 \%$ the water content of soil in the aerobic laboratory incubation (Figure 2). As soil water content declines below the optimum and soil temperatures become cooler, $\mathrm{N}$ mineralization declines (Cassman and Munns 1980). To correct for differences in $\mathrm{N}$ mineralization due to temperature between the laboratory incubation and the in situ method, field soil temperatures were used with $\mathrm{N}_{\mathrm{o}}$ and $\mathrm{k}$ estimates for the laboratory incubation to calculate $\mathrm{N}$ mineralization. The temperature corrected estimate of $292 \mathrm{~kg} \mathrm{ha}^{-1}$ is less that the $323 \mathrm{~kg} \mathrm{ha}^{-1}$ estimated for constant temperature but greater than the $139 \mathrm{~kg} \mathrm{ha}^{-1}$ estimated from the in situ method (Figure 3). Use of an intact soil core under fluctuating and lower moisture conditions that occurred with the in situ field method likely explain the lower $\mathrm{N}$ mineralization measured with this method compared to the aerobic laboratory incubation.

In 2004, the corn crop yielded $14.1 \pm 0.4 \mathrm{Mg} \mathrm{ha}^{-1}$ of grain and $11.7 \pm 1.8 \mathrm{Mg} \mathrm{ha}^{-1}$ of stover. The grain contained $248 \pm 11 \mathrm{~kg} \mathrm{~N}^{-1}$, and the stover contained $89 \pm 8 \mathrm{~kg} \mathrm{Nha}^{-1}$ for a total crop $\mathrm{N}$ content of

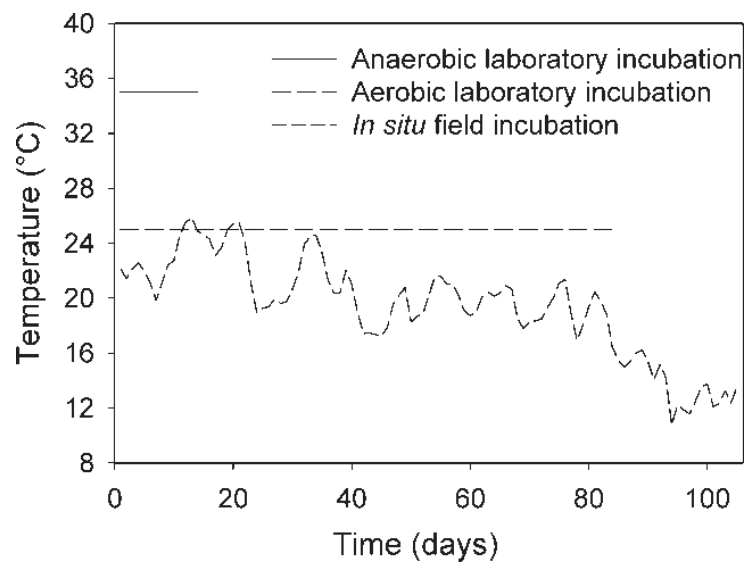

Figure 1. Temperature as a function of time for the three mineralization methods. 


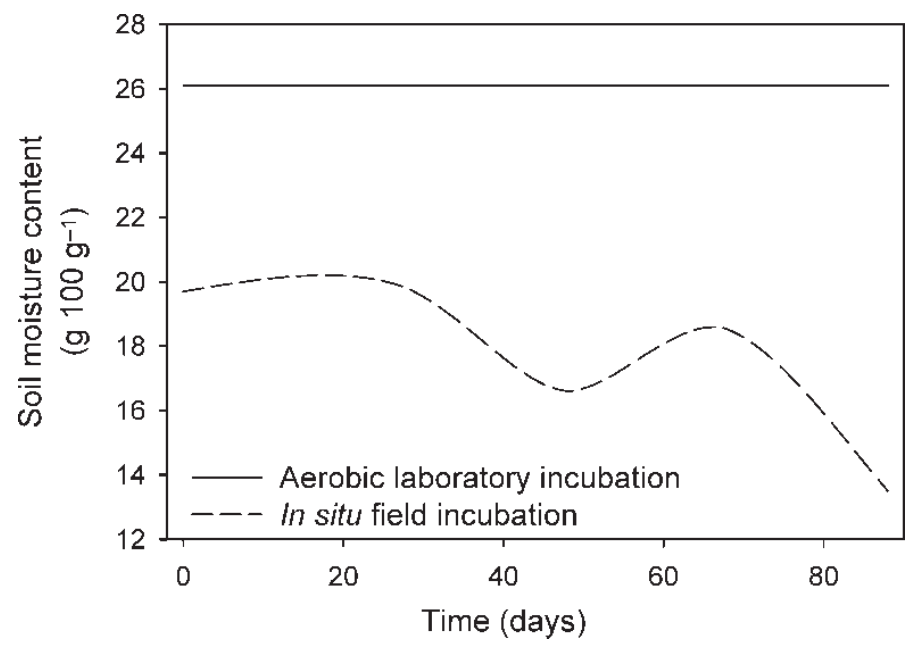

Figure 2. Soil water content as a function of time for the aerobic and in situ mineralization methods.

$337 \pm 27 \mathrm{~kg} \mathrm{ha}^{-1}$. At planting, the soil contained $56 \mathrm{~kg} \mathrm{ha}^{-1}$ of $\mathrm{NO}_{3}-\mathrm{N}$. The crop received $174 \mathrm{~kg} \mathrm{ha}^{-1}$ of fertilizer $\mathrm{N}$ and $70 \mathrm{~kg} \mathrm{ha}^{-1}$ of $\mathrm{N}$ in the irrigation water. Previous research using ${ }^{15} \mathrm{~N}$-labeled fertilizer has shown that $35 \%$ of the fertilizer is recovered in the grain and an additional $15 \%$ of th fertilizer is recovered in the stover in irrigated corn (Wienhold, Trooien, and Reichman 1995). Assuming a similar rate of fertilizer $\mathrm{N}$ use in this study results in $122 \mathrm{~kg} \mathrm{ha}^{-1}$ of the $\mathrm{N}$ contained in the crop originating with fertilizer

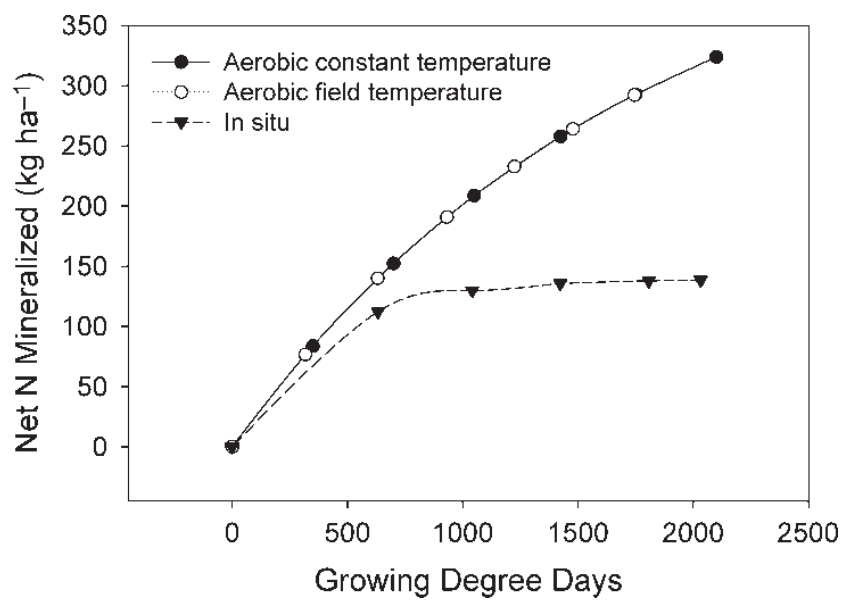

Figure 3. Net $\mathrm{N}$ mineralized as a function of growing degree days for the aerobic and in situ mineralization methods. 
and irrigation water inputs, leaving $215 \mathrm{~kg} \mathrm{ha}^{-1}$ of $\mathrm{N}$ being supplied by $\mathrm{N}$ mineralization. Comparing this value of $\mathrm{N}$ supplied by $\mathrm{N}$ mineralization to estimates in Table 2 suggests that the in situ field method provides the most reasonable estimate of mineralized $\mathrm{N}$ available for crop uptake. An $\mathrm{N}$-mineralization estimate slightly lower than the amount of mineralized $\mathrm{N}$ contributing to crop $\mathrm{N}$ content is reasonable because mineralization takes place throughout the root zone, and $\mathrm{N}$ mineralization was estimated for the 0 - to $15-\mathrm{cm}$ increment only.

Aerobic laboratory incubation under optimal conditions provides estimates of potential $\mathrm{N}$ mineralization that are greater than net $\mathrm{N}$ mineralization that occurs under field conditions. Anaerobic incubation, although fast, does not appear to accurately estimate $\mathrm{N}$ mineralization in the field. Although the laboratory methods do not appear to provide accurate estimates of $\mathrm{N}$ mineralization occurring in the field, they are useful for comparing $\mathrm{N}$ mineralization among soils. The in situ field method, although labor-intensive, provided reasonable estimates of $\mathrm{N}$ mineralization in the present study. Concerns with the in situ field method relate to water movement through the soil core and underlying resin. When large amounts of water pass through the soil cores, there is a concern that the resin will not be able to adsorb all inorganic $\mathrm{N}$ present in the leachate. Schnabel, Messier, and Purnell (1993) reported that resins were able to adsorb $80 \%$ of the nitrate contained in $500 \mathrm{~mm}$ of leachate that passed through soil fertilized with $300 \mathrm{~kg} \mathrm{ha}^{-1}$ of $\mathrm{N}$ and into the resin. Eghball (2000) reported that under field conditions, the resin used in our study was capable of adsorbing inorganic $\mathrm{N}$ equivalent to $275 \mathrm{~kg} \mathrm{~N} \mathrm{ha}^{-1}$, which is greater than the amount of inorganic $\mathrm{N}$ extracted in the present study.

A second concern about water movement through the soil and underlying resin relates to the potential for higher soil water contents in the tubes than in the adjacent soil caused by the textural discontinuity that exists between the resin and the soil. At higher soil water contents, there is a concern that denitrification losses may occur and $\mathrm{N}$ mineralization will be underestimated. Hanselman, Graetz, and Obreza (2004) documented higher water contents in mineralization tubes than in adjacent bulk soil for a sandy soil that received $780 \mathrm{~mm}$ of rain during the study. Even under these high-water-input conditions, the highest water content reported corresponded to $49 \%$ water-filled pore space (WFPS). This is less than the $60 \%$ WFPS where soil respiration is optimum and well less than the $80 \%$ WFPS where denitrification activity begins to increase rapidly (Linn and Doran 1984). Although water movement though the soil core may be modified by the presence of the underlying resin, water content and temperature fluctuate, creating conditions more similar to the bulk field soil than any of the laboratory methods.

An understanding of how management practices such as tillage intensity, crop sequence, and fertilizer amount, form, and placement affect $\mathrm{N}$ mineralization is incomplete. The in situ $\mathrm{N}$ mineralization method using intact soil cores 
under field conditions will likely provide more accurate estimates of $\mathrm{N}$ mineralization under various management scenarios than is possible using laboratory methods. Measurement of soil temperature and moisture along with in situ mineralization rates will provide the data sets needed to develop models for estimating $\mathrm{N}$-mineralization contributions to crop $\mathrm{N}$ budgets needed for calculating fertilizer $\mathrm{N}$ rates.

\section{ACKNOWLEDGMENTS}

The author thanks Susana Grigera and Sue Siragusa-Ortman for assistance in the field and Susan Wagner for conducting the laboratory analysis.

\section{REFERENCES}

Blake, G.R. and Hartge, K.H. (1986) Bulk density. In Methods of Soil Analysis Part 1: Physical and Mineralogical Methods, 2nd edn.; Klute, A. (ed.); American Society of Agronomy: Madison, Wisc, 363-375.

Bray, R.H. and Kurtz, L.T. (1945) Determination of total, organic, and available forms of phosphorus in soils. Soil Science, 59: 39-45.

Cassman, K.G. and Munns, D.N. (1980) Nitrogen mineralization as affected by soil moisture, temperature, and depth. Soil Science Society of America Journal, 44: $1233-1237$.

Distefano, J.F. and Gholz, H.L. (1986) A proposed use of ion-exchange resins to measure nitrogen mineralization and nitrification in intact soil cores. Communications in Soil Science and Plant Analysis, 17: 989-998.

Eghball, B. (2000) Nitrogen mineralization from field-applied beef cattle feedlot manure or compost. Soil Science Society of America Journal, 64: 2024-2030.

Eigenberg, R.A., Doran, J.W., Nienaber, J.A., Ferguson, R.B., and Woodbury, B.L. (2002) Electrical conductivity monitoring of soil condition and available $\mathrm{N}$ with animal manure and a cover crop. Agriculture, Ecosystems, and Environment, 88: $183-193$.

Gianello, C. and Bremner, J.M. (1986) Comparison of chemical methods of assessing potentially available organic nitrogen in soil. Communications in Soil Science and Plant Analysis, 17: 215-236.

Griffin, J.S. and Honeycutt, C.W. (2000) Using growing degree days to predict nitrogen availability from livestock manures. Soil Science Society of America Journal, 64: $1876-1882$.

Hanselman, T.A., Graetz, D.A., and Obreza, T.A. (2004) A comparison of in situ methods for measuring net nitrogen mineralization rates of organic soil amendments. Journal of Environmental Quality, 33: 1098-1105.

Johnson, C.K., Doran, J.W., Duke, H.R., Wienhold, B.J., Eskridge, K.M., and Shanahan, J.F. (2001) Field-scale electrical conductivity mapping for delineating soil condition. Soil Science Society of America Journal, 65: 1829-1837.

Keeney, D.R. (1982) Nitrogen—availability indices. In Methods of Soil Analysis Part 2: Chemical and Microbial Properties, 2nd edn.; Page, A.L., Miller, R.H., and Keeney, D.R. (eds.); American Society of Agronomy: Madison, Wisc., 711-733. 
Kettler, T.A., Doran, J.W., and Gilbert, T.L. (2001) A simplified method for soil particle size determination to accompany soil quality analyses. Soil Science Society of America Journal, 65: 849-852.

Kolberg, R.L., Rouppet, B., Westfall, D.G., and Peterson, G.A. (1997) Evaluation of an in situ net soil nitrogen mineralization method in dryland agroecosystems. Soil Science Society of America Journal, 61: 504-508.

Linn, D.M. and Doran, J.W. (1984) Effect of water-filled pore space on carbon dioxide and nitrous oxide production in tilled and nontilled soils. Soil Science Society of America Journal, 48: 1267-1272.

Ritchie, S.W., Hanway, J.J., and Benson, G.O. (1993) How a Corn Plant Develops; (Special Report Number 48), Ames, IA: Iowa State University.

SAS Institute. (1985). SAS User's Guide; SAS Institute Inc: Cary, N.C.

Schepers, J.S., Francis, D.D., and Thompson, M.T. (1989) Simultaneous determination of total C, total $\mathrm{N}$, and ${ }^{15} \mathrm{~N}$ on soil and plant material. Communications in Soil Science and Plant Analysis, 20: 949-959.

Schnabel, R.R., Messier, S.R., and Purnell, R.F. (1993) An evaluation of anion exchange resin used to measure nitrate movement through soil. Communications in Soil Science and Plant Analysis, 24: 863-879.

Smith, J.L. and Doran, J.W. (1996) Measurement and use of pH and electrical conductivity for soil quality analysis. In Methods for Assessing Soil Quality; Doran, J.W. and Jones, A.J. (eds.); (Soil Science Society of America Special Publication number 49) Soil Science Society of America: Madison, Wisc., 169-185.

Stanford, G. and Smith, S.J. (1972) Nitrogen mineralization potential of soils. Soil Science Society of America Proceedings, 36: 465-472.

Sudduth, K.A., Kitchen, N.R., Bollero, G.A., Bullock, D.G., and Wiebold, W.J. (2003) Comparison of electromagnetic induction and direct sensing of soil electrical conductivity. Agronomy Journal, 95: 472-482.

Waring, S.A. and Bremner, J.M. (1964) Ammonium production in soil under waterlogged conditions as an index of nitrogen availability. Nature (London) 201: 951-952.

Wienhold, B.J., Trooien, T.P., and Reichman, G.A. (1995) Yield and nitrogen use efficiency of irrigated corn in the northern great plains. Agronomy Journal, 59: 842-846. 